\title{
Acid transformation of bauxite residue: Conversion of its alkaline characteristics
}

by Kong, X., Li, M., Hartley, W., Wu, C., Li, X. and Li, Y.

Copyright, Publisher and Additional Information: This is the author accepted manuscript. The final published version (version of record) is available online via Elsevier Please refer to any applicable terms of use of the publisher.

DOI: http://dx.doi.org/10.1016/j.jhazmat.2016.10.073

Harper Adams

University

Kong, X., Li, M., Hartley, W., Wu, C., Li, X. and Li, Y. 2016. Acid transformation of bauxite residue: conversion of its alkaline characteristics. Journal of Hazardous Materials. 


\section{Accepted Manuscript}

Title: Acid transformation of bauxite residue: conversion of its alkaline characteristics

Author: Xiangfeng Kong Meng Li Shengguo Xue William Hartley Chengrong Chen Chuan Wu Xiaofei Li Yiwei Li

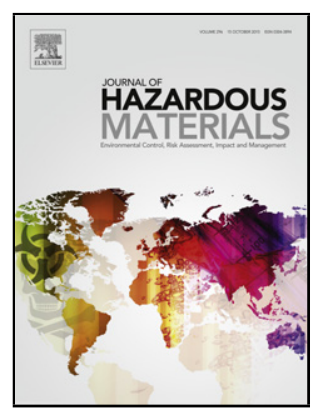

PII: $\quad$ S0304-3894(16)31004-4

DOI: $\quad$ http://dx.doi.org/doi:10.1016/j.jhazmat.2016.10.073

Reference: $\quad$ HAZMAT 18154

To appear in: $\quad$ Journal of Hazardous Materials

Received date: $\quad 1-8-2016$

Revised date: $\quad 18-10-2016$

Accepted date: $\quad 31-10-2016$

Please cite this article as: Xiangfeng Kong, Meng Li, Shengguo Xue, William Hartley, Chengrong Chen, Chuan Wu, Xiaofei Li, Yiwei Li, Acid transformation of bauxite residue: conversion of its alkaline characteristics, Journal of Hazardous Materials http://dx.doi.org/10.1016/j.jhazmat.2016.10.073

This is a PDF file of an unedited manuscript that has been accepted for publication. As a service to our customers we are providing this early version of the manuscript. The manuscript will undergo copyediting, typesetting, and review of the resulting proof before it is published in its final form. Please note that during the production process errors may be discovered which could affect the content, and all legal disclaimers that apply to the journal pertain. 


\section{Acid transformation of bauxite residue: conversion of its alkaline characteristics}

Xiangfeng Kong a, Meng Li ${ }^{\text {a }}$, Shengguo Xue ${ }^{\text {a,* }}$, William Hartley ${ }^{\text {b }}$, Chengrong Chen ${ }^{\mathrm{c}}$,

Chuan $\mathrm{Wu}^{\text {a }}$, Xiaofei $\mathrm{Li}^{\text {a }}$, Yiwei $\mathrm{Li}^{\text {a }}$

a School of Metallurgy and Environment, Central South University, 932 Lushan South Road, Changsha, Hunan, 410083, PR China

b Crop and Environment Sciences Department, Harper Adams University, Newport, Shropshire, TF10 8NB, United Kingdom

${ }^{\mathrm{c}}$ Griffith School of Environment, Griffith University, Nathan Campus, Qld 4111, Australia ${ }^{1}$

*Corresponding author. Tel: + 8673185552958.

E-mail address: sgxue70@hotmail.com (S.G.Xue); sgxue@csu.edu.cn. 

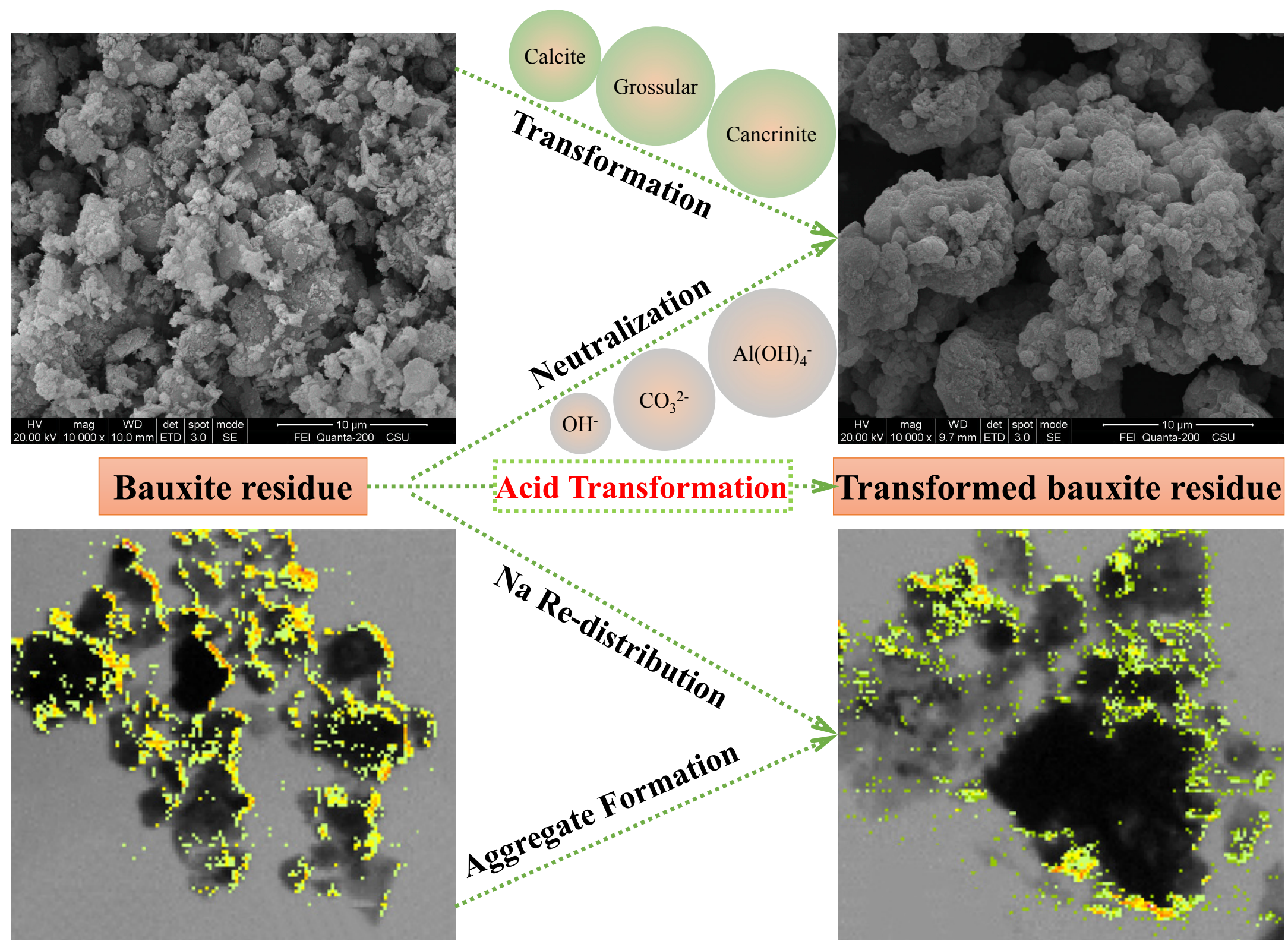

Acid Transformation $\Rightarrow$ Transformed bauxite residue

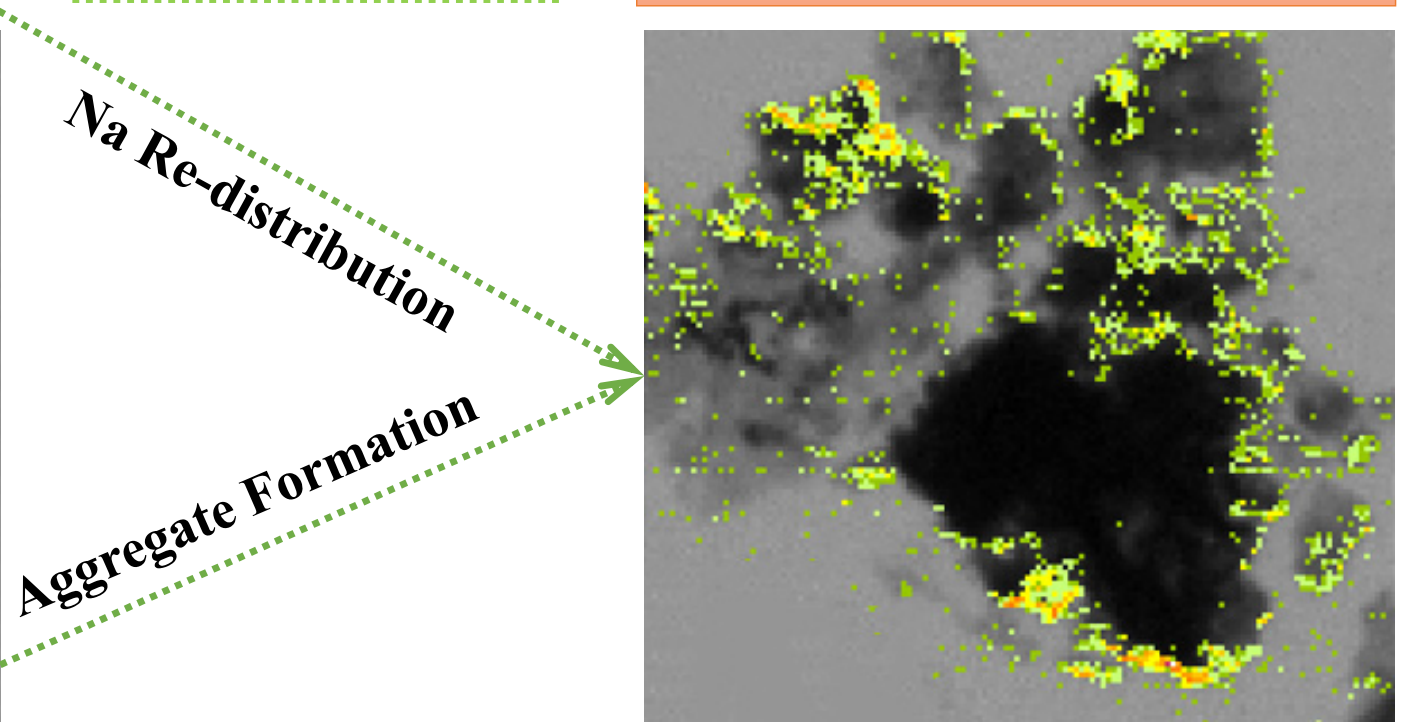




\title{
Highlights
}

- Speciation and transformation of solid and soluble alkalinities were investigated.

- SEM, NEXAFS, and STXM were used to observe particle morphology and alkaline Na speciation and distribution.

- Gypsum combination promoted leaching of Na-bearing solids and the replacement of exchangeable Na.

- The use of organic citric acid to transform bauxite residue alkalinity.

\begin{abstract}
Bauxite residue (BR) is a highly alkaline solid hazardous waste produced from bauxite processing for alumina production. Alkaline transformation appears to reduce the environmental risk of bauxite residue disposal areas (BRDAs) whilst potentially providing opportunities for the sustainable reuse and on-going management of BR. Mineral acids, a novel citric acid and a hybrid combination of acid-gypsum treatments were investigated for their potential to reduce residue $\mathrm{pH}$ and total alkalinity and transform the alkaline mineral phase. XRD results revealed that with the exception of andradite, the primary alkaline solid phases of cancrinite, grossular and calcite were transformed into discriminative products based on the transformation used. Supernatants separated from BR and transformed bauxite residue (TBR) displayed distinct changes in soluble $\mathrm{Na}, \mathrm{Ca}$ and $\mathrm{Al}$, and a reduction in $\mathrm{pH}$ and total alkalinity. SEM images suggest that mineral acid transformations promote macro-aggregate formation, and the positive promotion of citric acid, confirming the removal or reduction in soluble and exchangeable Na. NEXAFS analysis of Na K-edge revealed that the chemical speciation of Na in TBRs was consistent with BR. Three acid treatments and gypsum combination had no effect on Na speciation, which affects the distribution of Na revealed by sodium STXM imaging.
\end{abstract}

\section{Abbreviation list:}

BR Bauxite residue

HBR Bauxite residue transformed by hydrochloric acid

SBR Bauxite residue transformed by sulfuric acid

CBR Bauxite residue transformed by citric acid
TBR Transformed bauxite residue

HGBR Bauxite residue transformed by hydrochloric acid and gypsum

SGBR Bauxite residue transformed by sulfuric acid and gypsum

CGBR Bauxite residue transformed by citric and gypsum 
Keywords: Bauxite residue; Alkaline transformation; Organic acid; Gypsum combination; NEXAFS analysis.

\section{Introduction}

The alumina industry has been expanding rapidly due to the increasing demand for aluminum. Nevertheless, these rapid developments have caused multiple environmental issues which currently limit the sustainable development of the alumina industry $[1,2]$. Bauxite residue (BR, or red mud) is an alkaline solid waste generated during alumina extraction from bauxite using the Bayer, sintering and Bayer-sintering processes in refineries. The volume of bauxite residue generated per ton of alumina product is approximately $0.5-2$ tons [3-5]. Raising demand for alumina worldwide has increased the rate of bauxite residue production. Globally, the accumulative storage of bauxite residue has arrived at over 4 billion tons, and is still rapidly increasing [6-8], and as yet there is no economic alternative to landfill [9-13]. Therefore, almost all bauxite residue continues to be stored indefinitely in bauxite residue disposal areas (BRDAs) $[14,15]$, which require on-going efforts to manage the waste and lower its potential to contaminate water, occupy land and disturb the surrounding ecology [16-22]. Furthermore, leaching of alkaline waste from BRDAs is an added problem $[23,24]$. Additionally, freshly formed alkaline dust and efflorescence at the surfaces of BRDA's that contain large amounts of sodium are directly harmful to BRDA operatives [25].

As a consequence of using sodium hydroxide to digest alumina from bauxite and the formation of a complex-alkaline minerals the material is high alkaline. Formation of cancrinite $\left(\left[\mathrm{Na}_{6} \mathrm{Al}_{6} \mathrm{Si}_{6} \mathrm{O}_{24}\right] \cdot 2\left[\mathrm{CaCO}_{3}\right]\right)$, sodalite $\left(\left[\mathrm{Na}_{6} \mathrm{Al}_{6} \mathrm{Si}_{6} \mathrm{O}_{24}\right] \cdot\left[2 \mathrm{NaX}\right.\right.$ or $\left.\left.\mathrm{Na}_{2} \mathrm{X}\right]\right)$, tri-calcium aluminate (TCA, $\left.\mathrm{Ca}_{3} \mathrm{Al}_{2}(\mathrm{OH})_{12}\right)$ and hydrogarnet $\left(\mathrm{Ca}_{3} \mathrm{Al}_{2}\left(\mathrm{SiO}_{4}\right)_{x}(\mathrm{OH})_{12-4 x}\right)$ are typically alkaline minerals. These solids act as an alkaline resource and their dissolution reactions make for bauxite residue changing into extremely alkaline and serve to buffer the residue to a $\mathrm{pH}$ of approximately 11 [2628]. Residual sodium hydroxide $(\mathrm{NaOH})$, sodium aluminate $\left(\mathrm{NaAl}(\mathrm{OH})_{4}\right)$ and sodium carbonate $\left(\mathrm{Na}_{2} \mathrm{CO}_{3}\right)$ that can't be completely separated by counter-current decantation (CCD) water washing remain in the residue and are responsible for the soluble alkalinity. The leaching of alkaline ions $\left(\mathrm{OH}^{-}, \mathrm{Al}(\mathrm{OH})_{4}^{-}, \mathrm{CO}_{3}{ }^{2-}\right)$ provides some buffering capacity around $\mathrm{pH} 11$ to $8.3[29,30]$.

Neutralization of residues is commonly applied by the alumina industry to deal both with bauxite residue prior to disposal and as an amelioration technique for encouraging revegetation [31-34]. 
Seawater neutralization, gypsum transformation, carbon dioxide sequestration and waste acid interaction are frequent amelioration transformations that have been developed for reducing its alkalinity.

Seawater neutralization is applicable at some coastal refineries (e.g. Queensland Alumina, Australia; Shandong Aluminium Industry Co., Ltd, China), which transports excess seawater into bauxite residue and precipitates soluble hydroxides, aluminates and carbonates as indissoluble solids such as para-aluminohydrocalcite $\left(\mathrm{CaAl}_{2}\left(\mathrm{CO}_{3}\right)_{2}(\mathrm{OH})_{4} \cdot 3 \mathrm{H}_{2} \mathrm{O}\right)$, calcite $\left(\mathrm{CaCO}_{3}\right)$, hydrocalumite $\left(\mathrm{Ca}_{4} \mathrm{Al}_{2}(\mathrm{OH})_{12} \cdot \mathrm{CO}_{3}\right)$, brucite $\left(\mathrm{Mg}_{3}(\mathrm{OH})_{6}\right)$ and hydrotalcite $\left(\mathrm{Mg}_{6} \mathrm{Al}_{2}\left(\mathrm{CO}_{3}\right)(\mathrm{OH})_{16} \cdot 4 \mathrm{H}_{2} \mathrm{O}\right)($ Eqs.1-5) [14, 35-38]. But fruiting colloidal particles are subsequently disadvantageous to further store or remediate.

$$
\begin{aligned}
& 2 \mathrm{Al}(\mathrm{OH})_{4}{ }^{-}+2 \mathrm{CO}_{3}{ }^{2-}+\mathrm{Ca}^{2+} \rightarrow \mathrm{CaAl}_{2}\left(\mathrm{CO}_{3}\right)_{2}(\mathrm{OH})_{4} \cdot 3 \mathrm{H}_{2} \mathrm{O}+4 \mathrm{OH}^{-} \\
& \mathrm{CO}_{3}{ }^{2-}+\mathrm{Ca}^{2+} \rightarrow \mathrm{CaCO}_{3} \\
& 4 \mathrm{OH}^{-}+2 \mathrm{Al}(\mathrm{OH})_{4}{ }^{-}+\mathrm{CO}_{3}{ }^{2-}+4 \mathrm{Ca}^{2+} \rightarrow \mathrm{Ca}_{4} \mathrm{Al}_{2}(\mathrm{OH})_{12} \cdot \mathrm{CO}_{3} \\
& \mathrm{OH}^{-}+\mathrm{Mg}^{2+} \rightarrow \mathrm{Mg}_{3}(\mathrm{OH})_{6} \\
& \mathrm{OH}^{-}+\mathrm{CO}_{3}{ }^{2-}+\mathrm{Al}(\mathrm{OH})_{4}{ }^{-}+\mathrm{Mg}^{2+} \rightarrow \mathrm{Mg}_{6} \mathrm{Al}_{2}\left(\mathrm{CO}_{3}\right)(\mathrm{OH})_{16} \cdot 4 \mathrm{H}_{2} \mathrm{O}
\end{aligned}
$$

Gypsum transformation by a similar mechanism, hydroxides, aluminates and carbonates can be precipitated as calcium hydroxide $\left(\mathrm{Ca}(\mathrm{OH})_{2}\right)\left(\right.$ Eq. 6), tri-calcium aluminate $\left(\mathrm{Ca}_{3} \mathrm{Al}_{2}(\mathrm{OH})_{12}, \mathrm{TCA}\right)$ (Eq. 7), hydrocalumite $\left(\mathrm{Ca}_{4} \mathrm{Al}_{2}(\mathrm{OH})_{12} \cdot \mathrm{CO}_{3}\right)$ (Eq. 3) and calcite $\left(\mathrm{CaCO}_{3}\right)$ (Eq. 2) $[14,31,39,40]$. This technique is limited by the dissolved ability of gypsum and the rate of $\mathrm{Ca}^{2+}$ release into solution $[31,41]$. Additionally, gypsum's dissolution rate is profoundly controlled by BET surface area and common ion effects. Consequently, the effect of gypsum on the reduction of alkalinity are restricted.

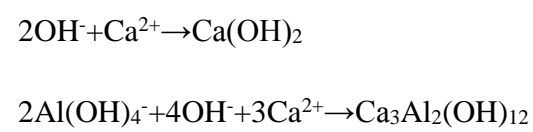

Carbon dioxide $\left(\mathrm{CO}_{2}\right)$ sequestration mainly uses the reaction of hydroxide $\left(\mathrm{OH}^{-}\right)$with $\mathrm{CO}_{2}$ to form $\mathrm{HCO}_{3}{ }^{-}$, and the key reversibly alkaline reactions between $\mathrm{OH}^{-}, \mathrm{CO}_{3}{ }^{2-}$ and $\mathrm{HCO}_{3}{ }^{-}$(Eqs. 8-10) $[9,40,42,43]$. Furthermore, with consumption of free $\mathrm{OH}^{-}, \mathrm{Al}(\mathrm{OH})_{4}{ }^{-}$will precipitate as gibbsite $\left(\mathrm{Al}(\mathrm{OH})_{3}\right)$ and possible dawsonite (Eqs. 11-13) [35, 44, 45]. Use of $\mathrm{CO}_{2}$ would also reduce the emission of industrial carbon dioxide, which could create an additional benefit. However, the conversions of sodalite and cancrinite are small, and components of these alkaline substances in bauxite residue can't be neutralized by $\mathrm{CO}_{2}[10,46]$. 


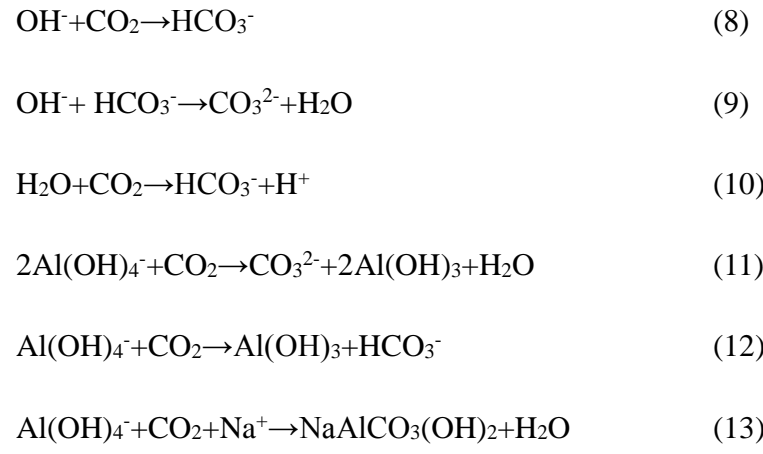

Interaction of waste acid can react with hydroxides and carbonates, even for oxides that may be leached [45, 47-49]. Dosing with waste acids is effective to lower $\mathrm{pH}$ and reduce alkaline substances, but nevertheless, the acid transformation of bauxite residue is controlled by a complicated set of chemistry reactions that depend upon the interaction between the solution phase and multiple solids $[15,29,50]$. Unfortunately, dissolution behavior of alkaline substances at a specific $\mathrm{pH}$ is absent, but is pivotal if a valid acid transformation theory is to be understood. Furthermore, less attention has been paid to acid-gypsum interactions and citric acid adopted to neutralize alkalinity. Limited understanding of interaction chemistry and alkalinity behavior of acid-gypsum combined processes and citric acid, has been highlighted as significant knowledge gap with reference to the alkalinity transformation and safe disposal of bauxite residue.

This study investigated free and chemical alkalinity behavior of bauxite residue transformed by six different methods: hydrochloric acid, a hybrid of hydrochloric acid and gypsum, sulfuric acid, a combination of sulfuric acid and gypsum, citric acid, a hybrid of citric acid and gypsum.

In this paper the following objectives were considered: Firstly to attempt to understand the transformation changes to bauxite residue following neutralization of both its solution and solid phases. Secondly to identify solid phase transformation products using X-ray diffraction, X-ray absorption spectroscopy, and electron and scanning transmission X-ray microscopy. Thirdly to investigate any interaction chemistry and alkalinity changes following addition of a hybrid combination of acid-gypsum remediation technique. Finally to attempt to understand the wellfounded acid transformation process on dissolution behavior of alkaline substance formation. 


\section{Materials and methods}

\subsection{Field sampling and sample preparation}

Fresh bauxite residue from Pingguo refinery, Aluminum Corporation of China, Guangxi province, China was collected in January 2015 (Lat $23^{\circ} 18^{\prime} 28.68^{\prime \prime} \mathrm{N}$, Long $107^{\circ} 31^{\prime} 8.15^{\prime \prime}$ E). Three subsamples were collected having a distance of 5 meters from each other. Samples were placed in polyethylene bags, and took to the lab and subsequently exposed to the air for 1 week then ovendried at $65{ }^{\circ} \mathrm{C}$ for $72 \mathrm{~h}$. Samples were then slightly disaggregated using a pestle and mortar, and sieved to keep up the $<2 \mathrm{~mm}$ fraction. Bauxite residues were transformed by hydrochloric acid (HBR), a hybrid of hydrochloric acid and gypsum (HGBR), sulfuric acid (SBR), a combination of sulfuric acid and gypsum (SGBR), citric acid (CBR), and a hybrid of citric acid and gypsum (CGBR), respectively. Samples $(60 \mathrm{~g})$ were equally weighed into six conical flasks $(100 \mathrm{ml})$, three acids $(\mathrm{HCl}$, $0.500 \mathrm{~mol} / \mathrm{L} ; \mathrm{H}_{2} \mathrm{SO}_{4}, 0.250 \mathrm{~mol} / \mathrm{L} ; \mathrm{H}_{3} \mathrm{Cit}, 0.167 \mathrm{~mol} / \mathrm{L}$ ) were respectively added at $1.6 \mathrm{ml}$ increments to an initial solid:liquid ratio of $1: 5$, to create a slurry and filled to volume (50 ml) with Milli-Q water (three acid treatments, i.e. $\mathrm{HCl}$ transformed bauxite residue, $\mathrm{HBR} ; \mathrm{H}_{2} \mathrm{SO}_{4}$ transformed bauxite residue, $\mathrm{SBR} ; \mathrm{H}_{3}$ Cit transformed bauxite residue, $\left.\mathrm{CBR}\right)$. Following this $\mathrm{CaSO}_{4} \cdot 2 \mathrm{H}_{2} \mathrm{O}(0.2 \mathrm{~g})(2 \%)$ was rapidly added to three samples treated with the three different acids, respectively (HGBR, SGBR, CGBR). The supernatant liquors were then shaken by hand and $\mathrm{pH}$ measured immediately by a calibrated $\mathrm{pH}$ probe [30]. Samples were then placed on a shaker operating at $120 \mathrm{rpm}\left(25^{\circ} \mathrm{C}\right)$. The suspensions were shaken for 60 days while measuring the supernatant liquor $\mathrm{pH}$. All three sub-samples of the six different methods (hydrochloric acid, a hybrid of hydrochloric acid and gypsum, sulfuric acid, a combination of sulfuric acid and gypsum, citric acid, a hybrid of citric acid and gypsum) were conducted to provide a statistically valid data set. After equilibration, the supernatants were centrifuged for $20 \mathrm{~min}$ at $4000 \mathrm{r} / \mathrm{min}$. Residual solids were washed twice in Milli-Q water, and characterized as below.

\subsection{Sample characterization}

Residual solids were oven-dried at $65^{\circ} \mathrm{C}$ and sieved to retain the $<0.38 \mu \mathrm{m}$ fraction prior to $\mathrm{X}$ ray powder diffraction (XRD) analysis conducted on a Bruker D8 discover 2500 with $\mathrm{Cu} K a_{1}$ tube using a Sol-X detector (LynxEye array). X-ray diffraction patterns were collected from 10 to $80^{\circ}$ at 
a step size of $0.04^{\circ} 2 \theta$ and a scan rate of $1^{\circ} 2 \theta / \mathrm{min}$. XRD data analysis used the PANalytical analysis package to identify and quantify phases. The relative intensity ratio method was used to quantitatively analyze mineral phases.

Scanning Electron Microscopy (SEM) of dried solids were examined on a FET Quanta-200. Solid powders were deposited on a Cu support plate with Au support film (conductive coating, deposited by low vacuum sputter coating) and examined by a GSED field emission gun.

Near edge X-ray absorption spectroscopy (NEXAFS) experiments were performed on the BL08U1A beamline of the Shanghai Synchrotron Radiation Facility (SSRF, Shanghai, China). NEXAFS spectra were collected at the Na K-edge $(1070.8 \mathrm{eV})$ that employed a double crystal monochromator consisting of beryllium (100 reflections), and the energy resolution was about 0.5 eV. Standard spectra of sodium were collected from SSRF chemicals of $\mathrm{Na}_{2} \mathrm{CO}_{3}$ and preparation of cancrinite. Sodium K-edge spectra were collected at the range of photon energy of 1065-1095 eV using the mode of total yield detection with $0.1 \mathrm{eV}$ step and $1 \mathrm{~s}$ counting time. All NEXAFS spectra were normalized and averaged using Athena 1.2.11 and plotted for residual solid samples and standards. In the meantime, distribution of $\mathrm{Na}$ in the residual solids was analyzed by synchrotron radiation based soft X-ray scanning transmission microscopy (STXM) technique.

Sodium, $\mathrm{K}, \mathrm{Ca}, \mathrm{Mg}, \mathrm{Al}$ and $\mathrm{Fe}$ concentrations in all supernatants and exchangeable $\mathrm{Na}, \mathrm{Ca}, \mathrm{Mg}$ and $\mathrm{K}$ extracted by $1 \mathrm{~mol} / \mathrm{L}$ ammonium acetate $(\mathrm{pH}=7)$ from the dried residual solids were analyzed by a PerkinElmer Optima 8000 ICP-OES.

\section{Results and discussion}

\subsection{Mineral chemistry}

The phases of BR and TBR and their quantitative quantities acquired by PANalytical analysis of XRD data show some apparent phase transformations in the transformation process (Table 1). The alkaline minerals from BR were andradite $\left(\mathrm{Ca}_{3}\left(\mathrm{Fe}_{0.87} \mathrm{Al}_{0.13}\right)_{2}\left(\mathrm{SiO}_{4}\right)_{1.65}(\mathrm{OH})_{5.4}\right)$, cancrinite $\left(\mathrm{Na}_{8} \mathrm{Al}_{6} \mathrm{Si}_{6} \mathrm{O}_{24}\left(\mathrm{CO}_{3}\right)\left(\mathrm{H}_{2} \mathrm{O}\right)_{2}\right)$, calcite $\left(\mathrm{CaCO}_{3}\right)$, and grossular $\left(\mathrm{Ca}_{3} \mathrm{Al}_{2} \mathrm{Si}_{3} \mathrm{O}_{12}\right)$, whilst a range of $\mathrm{Fe}$ oxide $\left(\mathrm{Fe}_{2} \mathrm{O}_{3}\right)$, a Ti mineral $\left(\mathrm{Ca}\left(\mathrm{TiO}_{3}\right)\right)$ and $\mathrm{Al}$ hydroxides $\left(\alpha-\mathrm{AlO}(\mathrm{OH})\right.$ and $\left.\mathrm{Al}(\mathrm{OH})_{3}\right)$ were also identified. The quantified XRD results (Table 1) indicate that BR contained $44.3 \%$ alkaline phases, which were dependant on bauxite source, digestion conditions and $\mathrm{CaO}$ addition [51]. The mineral 
characteristics of andradite, cancrinite, grossular and calcite in BR are fundamental to its high alkalinity, which are summarized as Eqs. 14-17 (dissolution reactions of buffering alkalinity solids).

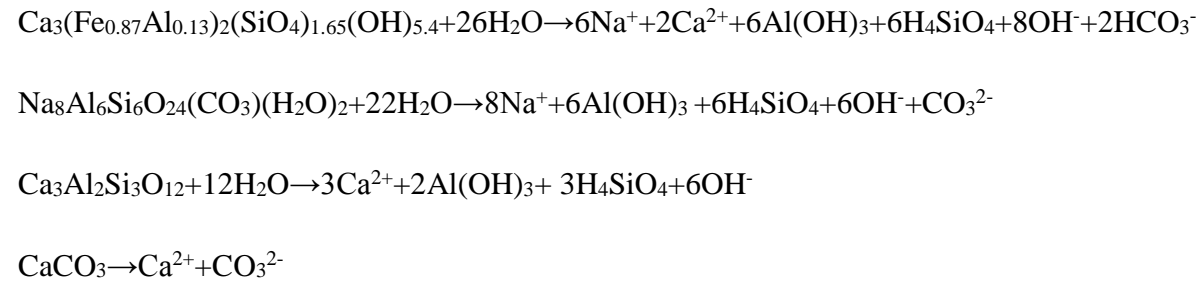

Andradite in BR and all TBRs (Table 1) indicate that andradite is primarily an alkaline mineral in the transformation. Quantification of andradite (Table 1) reveals that this phase was transformed by hydrochloric, sulfuric and citric acids and also in combination with gypsum, to form a stable residue due to its persistent chemical characteristics in acid solutions [52]. Calcite existed in BR (2.1\%), however it was not identified in all TBRs. Calcite results suggest that during acid transformation, calcite minerals are susceptible to acidic conditions, even for the citric acid treatment, which is easy to be dissolved into solution (Eq. 18). Additionally, the phenomenon of $\mathrm{CO}_{2}$ evolution may be observed at the beginning of acid dosing. Grossular results (Table 1) show that it was similar to calcite, and grossular peaks in HBR, HGBR, SBR, SGBR, CBR and CGBR were not observed in the XRD patterns (Fig. 1). Alkaline grossular minerals were transformed by hydrochloric, sulfuric and citric acids, whilst addition of gypsum resulted in the formation of weakly alkaline gibbsite precipitates and orthosilicic acid polymers (Eq. 19), partially increasing the gibbsite concentration in acid transformed residues. Orthosilicic acid slowly reacts with calcium resulting in the formation of calcium silicate precipitates (Eq. 20) with increasing calcium source through the addition of gypsum [53]. Calcium silicate minerals were present in HGBR (2\%), SGBR (2.2\%), and CGBR (2.3\%), but did not exist in HBR, SBR and CBR. Peaks for calcium silicate minerals were also observed in the XRD patterns (Fig. 1), which further confirms its formation.

$$
\begin{aligned}
& \mathrm{CaCO}_{3}+\mathrm{H}^{+} \rightarrow \mathrm{Ca}^{2+}+\mathrm{CO}_{2}+\mathrm{H}_{2} \mathrm{O} \\
& \mathrm{Ca}_{3} \mathrm{Al}_{2} \mathrm{Si}_{3} \mathrm{O}_{12}+\mathrm{H}^{+} \rightarrow 3 \mathrm{Ca}^{2+}+2 \mathrm{Al}(\mathrm{OH})_{3}+3 \mathrm{H}_{4} \mathrm{SiO}_{4} \\
& 2 \mathrm{Ca}^{2+}+\mathrm{H}_{4} \mathrm{SiO}_{4} \rightarrow \mathrm{Ca}_{2} \mathrm{SiO}_{4}+4 \mathrm{H}^{+}, \text {additional } \mathrm{Ca} \text { source, duration exceeds to } 28 \text { days }
\end{aligned}
$$

Cancrinite in BR and TBRs (Table 1) suggest that it was dissolved into solution following mineral and organic acid treatments. Nevertheless, transformation of cancrinite was different for hydrochloric, sulfuric and citric acids. Compared to the concentrations in TBRs, cancrinite concentrations in CBR (10.1\%) and CGBR (9.2\%) with mineral acids indicate that citric acid 
transformed more cancrinite into solution, whilst precipitating as gibbsite (Eqs. 21 and 22). The observed changes in peaks of cancrinite in XRD patterns are presented in Fig. 1. Transformation mechanisms for mineral acids (Eq. 23) are similar to citric acid except for the formation of sodium citrate, with the dissolution reaction controlled by acid mass transfer [54]. Citric acid may increase the apparent rate constant and activation energy of cancrinite [54], being beneficial to activate the reaction of cancrinite with citric acid.

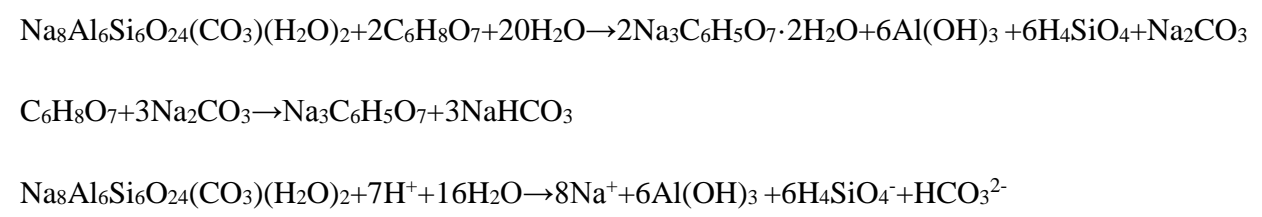

Furthermore, XRD results (Table 1 and Fig. 1) indicate a large quantity of hematite (approximately $36 \%)$ in BR and TBRs. The quantitative identification of hematite concentrations had no obvious change. Hematite remained steadily in residues generated from the different acid transformations because hematite transformation required more $\mathrm{H}^{+}$and was limited by the amount of soluble and solid phase alkalinities presented in the residues. Hematite will influence BR acid neutralizing capacity (ANC) in the range of $\mathrm{pH} 4$ to $5[50,55]$. Below pH 4 or 5 , hematite dissolution is constant, eventually exhausting the acid. Minerals including gibbsite and perovskite were also stable (Table 1). Results suggest that diaspore and perovskite were not transformed by hydrochloric, sulfuric or citric acid or by gypsum combination.

\subsection{Solution chemistry}

The supernatants from BR and TBR exhibit distinct changes in their alkalinity, $\mathrm{pH}, \mathrm{EC}$, soluble $\mathrm{Na}, \mathrm{K}, \mathrm{Ca}, \mathrm{Mg}, \mathrm{Al}$ and $\mathrm{Fe}$, and ammonium acetate-extractable $\mathrm{Na}, \mathrm{K}, \mathrm{Ca}$ and $\mathrm{Mg}$ (Table 2). Transformations resulted in $\mathrm{pH}$ decreases from $\mathrm{pH} 10.26$ in the supernatant of $\mathrm{BR}$ to $\mathrm{pH} 7.87$ (7.82) after $\mathrm{HCl}$ treatment (with gypsum addition), $\mathrm{pH} 8.22$ (8.07) after $\mathrm{H}_{2} \mathrm{SO}_{4}$ (with gypsum addition), and $\mathrm{pH} 8.49$ (8.23) after $\mathrm{C}_{6} \mathrm{H}_{8} \mathrm{O}_{7}\left(\mathrm{H}_{3} \mathrm{Cit}\right)$ treatment (with gypsum addition). Bauxite residue transformed by several different methods caused a similar reduction in $\mathrm{pH}$, whilst $\mathrm{pH}$ was marginally affected with gypsum. As expected, citric acid reacted with alkaline substances and resulted in a decrease in $\mathrm{pH}$ most likely related to alkaline anion speciation. Supernatants from all transformation methods revealed $\mathrm{pH}$ values lower than 8.3 , except $\mathrm{CBR}$, which was slightly higher, suggesting that the reactions of Eqs. 24-26 occurred in these solutions. Alkaline $\mathrm{OH} ., \mathrm{Al}(\mathrm{OH})_{4}{ }^{-}$and 
$\mathrm{CO}_{3}{ }^{2-}$ were all exhausted following the reactions (Table 2). Total alkalinity of TBRs decreased from $28.35 \mathrm{~g} / \mathrm{L} \mathrm{Na}_{2} \mathrm{CO}_{3}$ to $0.65 \mathrm{~g} / \mathrm{L} \mathrm{Na}_{2} \mathrm{CO}_{3}$, and no apparent difference between acid transformations and gypsum combination was observed.

$$
\begin{array}{ll}
\mathrm{H}^{+}+\mathrm{OH}^{-} \rightarrow \mathrm{H}_{2} \mathrm{O} & \text { buffer region: } \mathrm{pH}>10.3 \\
\mathrm{H}^{+}+\mathrm{Al}(\mathrm{OH})_{4}^{-} \rightarrow \mathrm{Al}(\mathrm{OH})_{3}+\mathrm{H}_{2} \mathrm{O} & \text { buffer region: down to approximately } \mathrm{pH} 10 \\
\mathrm{H}^{+}+\mathrm{CO}_{3}{ }^{2-} \rightarrow \mathrm{HCO}_{3}^{-} & \text {buffer region: down to approximately } \mathrm{pH} 8.3
\end{array}
$$

EC increased from $1.80 \mathrm{mS} / \mathrm{cm}$ to 4.08 (HBR), 4.79 (HGBR), 4.36 (SBR), 5.10 (SGBR), 3.95 (CBR) and 6.74 (CGBR). Raised EC's revealed distinct difference between BR and TBR. HBR and HGBR raised EC most likely through dissolution of $\mathrm{Na}$ minerals (soluble $\mathrm{Na}$ concentrations in supernatants is presented in Table 2). SBR and SGBR increased EC because of the solubilisation of $\mathrm{Na}$ (quantitative phase changes presented in Table 1), $\mathrm{Ca}$ and Mg minerals (Table 2). CBR and CGBR elevated $\mathrm{EC}$ as a result of the dissolution of $\mathrm{Na}, \mathrm{Ca}$, and $\mathrm{Mg}$, furthermore, citric acid transformation may result in $\mathrm{Al}$ minerals being leached into supernatants (Table 2). Precipitation of the aluminate ion occurred between $\mathrm{pH} 8.23$ to 8.49 , but the soluble $\mathrm{Al}$ in supernatants of $\mathrm{CBR}$ and CGBR was the result of formation of Al clathrate with citric acid [56]. Additionally, the high EC values in all supernatants from TBR revealed high concentrations of $\mathrm{Na}^{+}$, suggesting that Na-bearing solids in bauxite residue were correspondingly decreasing [57].

Soluble Na dominated the soluble cations in supernatants of BR, HBR, HGBR, SBR, SGBR, CBR and CGBR (Table 2) as a result of the partial dissolution of cancrinite (Table 1). Soluble Ca (Table 2) revealed that an initial concentration of $2.20 \mathrm{mg} / \mathrm{kg}$ in BR, was most likely from dissolution of calcite (solubility product constant i.e. $p K_{\mathrm{sp}}=8.42$ ) [58], but this increased to 830 $\mathrm{mg} / \mathrm{kg}$ in HBR and HGBR, $900 \mathrm{mg} / \mathrm{kg}$ in SBR and SGBR and $740 \mathrm{mg} / \mathrm{kg}$ in CBR and CGBR. This suggests that most calcite and grossular were transformed by acid and entered into supernatants. Additionally, Ca integrated with silicate from the precipitation of calcium silicate (Eq. 20, Table 1 and Fig. 1 presented), resulted in a decrease of soluble Ca in supernatants. Soluble K and Mg results (Table 2) indicate that $\mathrm{K}$ and $\mathrm{Mg}$ are present in BR. Kalium concentration in supernatant increased ( $\sim 30 \%)$, suggesting that most $\mathrm{K}$ in BR was soluble, and acid transformation will mildly influence $\mathrm{K}$ phase changes. Magnesium in BR was insoluble and acid treatments improved the Mg mineral dissolution most likely by leaching into supernatants. Iron in bauxite residue did not dissolve and remained stable in residues following the acid transformation processes, suggesting that acid 
transformation of alkaline andradite in bauxite residue does not occur.

Transformation results of exchangeable cations ( $\mathrm{Na}, \mathrm{K}, \mathrm{Ca}, \mathrm{Mg}$ ) presented in Fig. 2 show that exchangeable $\mathrm{Na}$ decreased with acid treatments and gypsum addition, whilst exchangeable $\mathrm{Ca}$ increased with these transformations, and exchangeable $\mathrm{K}$ and $\mathrm{Mg}$ changed slightly. For BR, the mass concentrations of varieties of exchangeable cations are in the follow-up decreasing order: $\mathrm{Ca}>\mathrm{Na}>\mathrm{K}>\mathrm{Mg}$. Exchangeable $\mathrm{Na}$ accounts for approximately $38 \%$ of the total exchangeable cations (mean mass concentration). The concentration of exchangeable Na decreased from 132.85 $\mathrm{mg} / \mathrm{kg}$ in BR to $91.46 \mathrm{mg} / \mathrm{kg}$ in HBR, $25.12 \mathrm{mg} / \mathrm{kg}$ in SBR, and $33.94 \mathrm{mg} / \mathrm{kg}$ in CBR, respectively. However, the concentration of exchangeable $\mathrm{Ca}$ increased and dominated the exchangeable basic cations in transformed bauxite residue, indicating that a large concentration of exchangeable Na was replaced with exchangeable Ca during transformation processes, also, gypsum addition promoted its replacement. This should be attributed to a reduction in $\mathrm{pH}$ (changes shown in Table 2) over transformation process, resulting in the initially negatively-charged alkaline compounds becoming zero-charged [59], which leads to reducing alkalinity of the residue by means of cation exchange (i.e. Ca source contributing to alkalinity relief). Additionally, high concentrations of exchangeable $\mathrm{Na}$ in $\mathrm{BR}$ is the main concern given the relationship to colloidal dispersion that would result in poor structural characteristics of bauxite residue particles [60]. Exchangeable Na in TBR suggests that mineral acids, citric acid and gypsum-combination change the cation exchange sites on the surface of BR. The effect is that particles of BR do not aggregate well, and generally trend to be crusted and eroded, but the poor structural conditions may gradually be ameliorated by mineral acids, citric acid and gypsum addition transformations.

\subsection{Morphology characteristics}

SEM imaging of the BR (Fig. 3 A) shows that it was composed of 0.1-0.5 $\mu \mathrm{m}$ particles in $2-5 \mu \mathrm{m}$ aggregates. Particles of BR were poorly-crystallized, containing amorphous substances, which were relatively dispersed and disorder. After mineral acid transformations, the aggregate particles of TBR (Fig. 3 B and C) were enriched and uniformly distributed. Small particles were not observed, which may have been leached in the mineral acid transformation processes, whilst others formed new aggregates. Mineral acid transformations promote the formation of macro-aggregates (Fig. $3 \mathrm{C}$ ), and gypsum addition (Fig. 3 D) accelerates this behavior improving aggregate stability due to 
calcium's positive effect on particle flocculation [61-63]. SEM imaging of CBR and CGBR (Fig. 3 E) revealed that it consisted of $0.2-1 \mu \mathrm{m}$ particles in approximately $10 \mu \mathrm{m}$ aggregates. Smaller grains remained in CBR, but almost disappearing in CGBR. The macro-aggregate particles of CBR and CGBR increased were regularly distributed. Fig. $3 \mathrm{E}$ and F suggest that citric acid transformation may also promote macro-aggregate formation, the citric acid being superior to mineral acids. Citric acid combined with gypsum addition not only improved the formation of macro-aggregates but also increased the macro-aggregate distribution. ]In addition, citric acid transformation may enhance the removal of $\mathrm{Na}$ from $\mathrm{BR}$ (Table 2) and prove beneficial towards improving BR physical conditions.

The Na K-edge X-ray absorption near edge structure (XANES) spectra (Fig. 4) collected from TBRs, had two prominent absorption peaks $b$ and $e$, near 1076.2 and $1080.0 \mathrm{eV}$ (quoted to $\pm 0.2 \mathrm{eV}$ ). Peak $b$ had a normalized adsorption intensity of 1.02, whilst peak $e$ had a normalized adsorption intensity of 1.23. The XANES spectrum of BR (Fig. 4) also had two major feature peaks at 1076.0 and $1080.2 \mathrm{eV}$, with normalized intensities of 1.02 and 1.26, respectively. A small feature peak was also clearly apparent at $1074.2 \mathrm{eV}$ with normalized intensities of 0.05 . XANES spectra for reference materials were obtained from cancrinite and $\mathrm{Na}_{2} \mathrm{CO}_{3}$ (cancrinite, adsorption peaks of $b$ and $e$ at 1076.2 and $1080.0 \mathrm{eV}$, normalized intensities of 1.02 and $1.23 ; \mathrm{Na}_{2} \mathrm{CO}_{3}$, absorption peak at 1079.6 $\mathrm{eV}$ with a normalized intensity of 1.07 ; pre-edge peak at $1074.4 \mathrm{eV}$ with a normalized intensity of 0.06). The two feature peaks at 1079.6 and $1074.4 \mathrm{eV}$ in the reference $\mathrm{Na}_{2} \mathrm{CO}_{3} \mathrm{XANES}$ spectrum had a similar intensity and position as that of BR, but the peak at 1074.4 was not observed in TBR spectra, implying that alkaline $\mathrm{Na}_{2} \mathrm{CO}_{3}$ likely existed in $\mathrm{BR}$ (not presented in Table 1 due to its content being lower than the detection limit), but it was leached into the supernatant and reduced the alkalinity of BR in the acid transformation process.

XANES analysis of Na K-edge indicated that two prominent absorption peaks $b$ and $e$ from BR and all TBRs, were almost uniform and similar to the cancrinite spectrum. The local ordering around $\mathrm{Na}$ ( $\mathrm{Na}$ is in a tetrahedral position surrounded by one $\mathrm{CO}_{3}$ at $2.701 \AA$ and three $\mathrm{O}$ at $2.398 \AA$ in a trigonal pyramid) did not change in residues [64]. Absorption peaks of cancrinite suggested that the chemical speciation of $\mathrm{Na}$ in residues was consistent with $\mathrm{BR}$, proving that alkaline cancrinite dominated Na speciation in TBRs, and further confirms that the three acid treatments and gypsum combination did not transform its chemical speciation. Nevertheless, Na distribution (sodium STXM imaging presented in Fig. 5) was obviously discriminative between BR and TBRs. TBR Na 
distributions were diluted in size, which further influenced the reduction in alkalinity of BR. Though BR treated with mineral and organic acids had no effect on Na speciation in residues, Na STXM imaging highlights the re-distribution of $\mathrm{Na}$.

\subsection{Implications for bauxite residue disposal}

Mineral acids, organic acid and gypsum combination used in alkaline transformations of BR were successful in decreasing total alkalinity and $\mathrm{pH}$ to some degree. Depending on the transformation processes, all soluble alkalinity removals were achieved by means of neutralization of hydroxides and carbonates and precipitation of aluminate ions, whilst alkaline solid phases of grossular, calcite and partial cancrinite were transformed.

Nevertheless, global clean-up of $\sim 4$ billion tons of bauxite residue, using mineral acids may not be practical considering cost implications. However, waste hydrochloric acid from steel manufacture and metal-product industries following iron rust removal and large quantities of waste sulfuric acid produced by copper refineries would guarantee a steady supply. Even so it is unlikely that these acids would be transported over large distances. Additionally, mineral acid leachate may further threaten the surrounding environment. If the supply of mineral acids and treatment of leachates could be resolved economically, then alkaline transformation of bauxite residue in BRDAs may warrant further investigation.

The results of citric acid transformation are an important step in transforming alkaline substances and reducing alkaline characteristics, especially for cancrinite conversion. Furthermore, the products of sodium citrate are safe, biodegradable and soluble. More importantly, citric acid commonly originates from the fermentation of starch materials. Use of citric acid may therefore be considered as a promising way forward, as starchy materials can be conveniently sourced and directly fermented in BRDAs.

\section{Conclusions}

This work presents evidence for the transformation of bauxite residue using three acids and an acid-gypsum combination, in order to reduce its $\mathrm{pH}$ and total alkalinity, consume soluble alkaline anions, replace exchangeable $\mathrm{Na}$, induce macro-aggregate formation and attempt to alter $\mathrm{Na}$ speciation and distribution. The main alkaline solid phases of grossular, calcite and partial cancrinite 
in BR were transformed and discriminative products were formed by the treatments. Citric acid can activate the reaction of cancrinite and promote its transformation. All transformation processes reduced $\mathrm{pH}$ and total alkalinity, exhausted alkaline $\mathrm{OH}^{-}, \mathrm{CO}_{3}{ }^{2-}$ and precipitated $\mathrm{Al}(\mathrm{OH})_{4}^{-}$. Gypsumacid combination promoted leaching of Na-bearing solids and the replacement of exchangeable $\mathrm{Na}$. Mineral acid transformations promoted macro-aggregate formation, and citric acid increased macroaggregate distribution, revealing the beneficial improvement to the residues physical properties. The three acid treatments and gypsum-acid combination had no effect on Na speciation, but affected the distribution of $\mathrm{Na}$ in the mesoporous range. Citric acid transformation is an important step in transforming alkalinity and may probably be considered as a promising way forward in an attempt to remediate BRDAs. More importantly, these findings are beneficial in order to reduce environment risk and provide further opportunities for the sustainable reuse and continuing management of bauxite residue.

\section{Acknowledgments}

This study was funded by the Environmental Protection's Special Scientific Research for Chinese Public Welfare Industry (Grant number 201509048), the National Natural Science Foundation of China (Grant number 41371475), and the Innovative Project of Independent Exploration for PhD of Central South University (Grant number 2016zzts036). The authors thank the Shanghai Synchrotron Radiation Facility for use of the synchrotron facilities at beamlines BL 08U. The authors sincerely acknowledge the anonymous reviewers for their insights and comments to further improve the quality of the manuscript. 


\section{References}

[1] A. Gelencser, N. Kovats, B. Turoczi, A. Rostasi, A. Hoffer, K. Imre, I. Nyiro-Kosa, D. CsakberenyiMalasics, A. Toth, A. Czitrovszky, A. Nagy, S. Nagy, A. Acs, A. Kovacs, A. Ferincz, Z. Hartyani, M. Posfai, The red mud accident in Ajka (Hungary): Characterization and potential health effects of fugitive dust, Environ. Sci. Technol. 45 (2011) 1608-1615, http://dx.doi.org/ 10.1021/es104005r.

[2] S. Ruyters, J. Mertens, E. Vassilieva, B. Dehandschutter, A. Poffijn, E. Smolders, The red mud accident in Ajka (Hungary): Plant toxicity and trace metal bioavailability in red mud contaminated soil, Environ. Sci. Technol. 45 (2011) 1616-1622, http://dx.doi.org/10.1021/es104000m.

[3] S.G. Xue, X.F. Kong, F. Zhu, W. Hartley, X.F. Li, Y.W. Li, Proposal for management and alkalinity transformation of bauxite residue in China, Environ. Sci. Pollut. R. 23 (2016) 1-13, http://dx.doi.org/10.1007/s11356-016-6478-7.

[4] F. Zhu, S.G. Xue, W. Hartley, L. Huang, C. Wu, X.F. Li, Novel predictors of soil genesis following natural weathering processes of bauxite residues, Environ. Sci. Pollut. R. 23 (2016) 2856-2863, http://dx.doi.org/10.1007/s11356-015-5537-9.

[5] T.C. Santini, J.L. Kerr, L.A. Warren, Microbially-driven strategies for bioremediation of bauxite residue, J. Hazard. Mater. 293 (2015) 131-157, http://dx.doi.org/10.1016/j.jhazmat.2015.03.024.

[6] T. Kinnarinen, L. Holliday, A. Hakkinen, Dissolution of sodium, aluminum and caustic compounds from bauxite residues, Miner. Eng. 79 (2015) 143-151, http://dx.doi.org/10.1016/j.mineng. 2015.06.007.

[7] Y. Liu, R. Naidu, Hidden values in bauxite residue (red mud): Recovery of metals, Waste Manage. 34 (2014) 2662-2673, http://dx.doi.org/10.1016/j.wasman.2014.09.003.

[8] G. Power, M. Grafe, C. Klauber, Bauxite residue issues: I. Current management, disposal and storage practices, Hydrometallurgy 108 (2011) 33-45, http://dx.doi.org/10.1016/j.hydromet.2011. 02.006

[9] V.S. Yadav, M. Prasad, J. Khan, S.S. Amritphale, M. Singh, C.B. Raju, Sequestration of carbon dioxide $\left(\mathrm{CO}_{2}\right)$ using red mud, J. Hazard. Mater. 176 (2010) 1044-1050, http://dx.doi.org/10.1016/ j.jhazmat.2009.11.146.

[10] S.B. Rai, K.L. Wasewar, R.S. Mishra, P. Mahindran, M.J. Chaddha, J. Mukhopadhyay, C. Yoo, Sequestration of carbon dioxide in red mud, Desalin. Water Treat. 51 (2013) 2185-2192, http:// dx.doi.org/10.1080/19443994.2012.734704.

[11] S. Wang, H.M. Ang, M.O. Tade, Novel applications of red mud as coagulant, adsorbent and catalyst for environmentally benign processes, Chemosphere 72 (2008) 1621-1635, http://dx.doi.org/ 10.1016/j.chemosphere.2008.05.013.

[12] J. Somlai, V. Jobbagy, J. Kovacs, S. Tarjan, T. Kovacs, Radiological aspects of the usability of red mud as building material additive, J. Hazard. Mater. 150 (2008) 541-545, http://dx.doi.org/ 10.1016/j.jhazmat.2007.05.004.

[13] R. Courtney, L. Kirwan, Gypsum amendment of alkaline bauxite residue - Plant available aluminium and implications for grassland restoration, Ecol. Eng. 42 (2012) 279-282, http://dx.doi.org/ 10.1016/j.ecoleng.2012.02.025.

[14] I.T. Burke, C.L. Peacock, C.L. Lockwood, D.I. Stewart, R.J.G. Mortimer, M.B. Ward, P. Renforth, K. Gruiz, W.M. Mayes, Behavior of aluminum, arsenic, and vanadium during the neutralization of red mud leachate by $\mathrm{HCl}$, gypsum, or seawater, Environ. Sci. Technol. 12 (2013) 6527-6535, http://dx.doi.org/10.1021/es4010834.

[15] X.B. Zhu, W. Li, X.M. Guan, An active dealkalization of red mud with roasting and water leaching, 
J. Hazard. Mater. 286 (2015) 85-91, http://dx.doi.org/10.1016/j.jhazmat.2014.12.048.

[16] N.C. Banning, Y. Sawada, I.R. Phillips, D.V. Murphy, Amendment of bauxite residue sand can alleviate constraints to plant establishment and nutrient cycling capacity in a water-limited environment, Ecol. Eng. 62 (2014) 179-187, http://dx.doi.org/10.1016/j.ecoleng.2013.10.034.

[17] C.L. Lockwood, D.I. Stewart, R.J. Mortimer, W.M. Mayes, A.P. Jarvis, K. Gruiz, I.T. Burke, Leaching of copper and nickel in soil-water systems contaminated by bauxite residue (red mud) from Ajka, Hungary: the importance of soil organic matter, Environ. Sci. Pollut. R. 22 (2015) 1080010810, http://dx.doi.org/10.1007/s11356-015-4282-4.

[18] W.C. Liu, X.Q. Chen, W.X. Li, Y.F. Yu, K. Yan, Environmental assessment, management and utilization of red mud in China, J. Clean. Prod. 84 (2014) 606-610, http://dx.doi.org/ 10.1016/j.jclepro.2014.06.080.

[19] S.G. Xue, F. Zhu, X.F. Kong, C. Wu, L. Huang, N. Huang, W. Hartley, A review of the characterization and revegetation of bauxite residues (Red mud), Environ. Sci. Pollut. R. 23 (2016) 1120-1132, http://dx.doi.org/10.1007/s11356-015-4558-8.

[20] N. Ye, J.K. Yang, X. Ke, J. Zhu, Y.L. Li, C. Xiang, H.B. Wang, L. Li, B. Xiao, Synthesis and characterization of Geopolymer from Bayer red mud with thermal pretreatment, J. Am. Ceram. Soc. 97 (2014) 1652-1660, http://dx.doi.org/10.1111/jace.12840.

[21] F. Zhu, J.Y. Zhou, S.G. Xue, W. Hartley, C. Wu, Y. Guo, Aging of bauxite residue in association of regeneration: a comparison of methods to determine aggregate stability \& erosion resistance, Ecol. Eng. 92 (2016) 47-54, http://dx.doi.org/10.1016/j.ecoleng.2016.03.025.

[22] C. Wu, Q. Zou, S.G. Xue, W.S. Pan, X. Yue, W. Hartley, L. Huang, J.Y. Mo, Effect of silicate on arsenic fractionation in soils and its accumulation in rice plants, Chemosphere 165 (2016) 478-486, http://dx.doi.org/10.1016/j.chemosphere.2016.09.061.

[23] I.D. Pulford, J.S.J. Hargreaves, J. Durisova, B. Kramulova, C. Girard, M. Balakrishnan, V.S. Batra, J.L. Rico, Carbonised red mud - A new water treatment product made from a waste material, J. Environ. Manage. 100 (2012) 59-64, http://dx.doi.org/10.1016/j.jenvman.2011.11.016.

[24] S. Samal, A.K. Ray, A. Bandopadhyay, Characterization and microstructure observation of sintered red mud - fly ash mixtures at various elevated temperature, J. Clean. Prod. 101 (2015) 368-376, http://dx.doi.org/10.1016/j.jclepro.2015.04.010

[25] C. Klauber, N. Harwood, R. Hockridge, C. Middleton, Proposed mechanism for the formation of dust horizons on bauxite residue disposal area, Essential Readings in Light Metals: Alumina and Bauxite, Volume 1ed., John Wiley \& Sons, Inc., 2013.

[26] B.I. Whittington, B.L. Fletcher, C. Talbot, The effect of reaction conditions on the composition of desilication product (DSP) formed under simulated Bayer conditions, Hydrometallurgy 49 (1998) 1-22, http://dx.doi.org/10.1016/S0304-386X(98)00021-8.

[27] M. Paradis, J. Duchesne, A. Lamontagne, D. Isabel, Long-term neutralisation potential of red mud bauxite with brine amendment for the neutralisation of acidic mine tailings, Appl. Geochem. 22 (2007) 2326-2333, http://dx.doi.org/10.1016/j.apgeochem.2007.04.021.

[28] A.K. Suryavanshi, J.D. Scantlebury, S.B. Lyon, Mechanism of Friedel's salt formation in cements rich in tri-calcium aluminate, Cement Concrete Res. 26 (1999) 717-727, http://dx.doi.org/10.1016/ S0008-8846(96)85009-5.

[29] L.J. Kirwan, A. Hartshorn, J.B. McMonagle, L. Fleming, D. Funnell, Chemistry of bauxite residue neutralisation and aspects to implementation, Int. J. Miner. Process. 119 (2013) 40-50, http:// dx.doi.org/10.1016/j.minpro.2013.01.001. 
[30] M.W. Clark, M. Johnston, A.J. Reichelt-Brushett, Comparison of several different neutralisations to a bauxite refinery residue: Potential effectiveness environmental ameliorants, Appl. Geochem. 56 (2015) 1-10, http://dx.doi.org/10.1016/j.apgeochem.2015.01.015.

[31] R. Courtney, T. Harrington, Growth and nutrition of Holcus lanatus in bauxite residue amended with combinations of spent mushroom compost and gypsum, Land Degrad. Dev. 23 (2012) 144-149, http://dx.doi.org/10.1002/ldr.1062.

[32] H. Genc-Fuhrman, J.C. Tjell, D. Mcconchie, Adsorption of arsenic from water using activated neutralized red mud, Environ. Sci. Technol. 38 (2004) 2428-2434, http://dx.doi.org/10.1021/ es035207h.

[33] A.R. Hind, S.K. Bhargava, S.C. Grocott, The surface chemistry of Bayer process solids: a review, Colloids and Surfaces A: Physicochemical and Engineering Aspects 146 (1999) 359-374, http://dx.doi.org/10.1016/S0927-7757(98)00798-5.

[34] M. Kishida, T. Harato, C. Tokoro, S. Owada, In situ remediation of bauxite residue by sulfuric acid leaching and bipolar-membrane electrodialysis, Hydrometallurgy (2016), http://dx.doi.org/ 10.1016/j.hydromet.2016.04.012.

[35] M.W. Clark, M. Johnston, A.J. Reichelt-Brushett, Comparison of several different neutralisations to a bauxite refinery residue: Potential effectiveness environmental ameliorants, Appl. Geochem. 56 (2015) 1-10, http://dx.doi.org/10.1016/j.apgeochem.2015.01.015.

[36] M. Johnston, M.W. Clark, P. McMahon, N. Ward, Alkalinity conversion of bauxite refinery residues by neutralization, J. Hazard. Mater. 182 (2010) 710-715, http://dx.doi.org/10.1016/j.jhazmat. 2010.06.091.

[37] C. Hanahan, D. Mcconchie, R. Creelman, Chemistry of seawater neutralization of bauxite refinery residues (red mud), Environ. Eng. Sci. 21 (2004) 125-138, http://dx.doi.org/10.1089/ 109287504773087309.

[38] N.W. Menzies, I.M. Fulton, W.J. Morrell, Seawater neutralization of alkaline bauxite residue and implications for revegetation, J. Environ. Qual. 33 (2004) 1877-1884, http://dx.doi.org/10.2134/ jeq2004.1877.

[39] A. Giridhar Babu, M. Sudhakara Reddy, Influence of arbuscular mycorrhizal fungi on the growth and nutrient status of bermudagrass grown in alkaline bauxite processing residue, Environ. Pollut. 159 (2011) 25-29, http://dx.doi.org/10.1016/j.envpol.2010.09.032.

[40] P. Renforth, W.M. Mayes, A.P. Jarvis, I.T. Burke, D.A.C. Manning, K. Gruiz, Contaminant mobility and carbon sequestration downstream of the Ajka (Hungary) red mud spill: The effects of gypsum dosing, Sci. Total Environ. 421-422 (2012) 253-259, http://dx.doi.org/10.1016/j.scitotenv. 2012.01.046.

[41] R.G. Courtney, S.N. Jordan, T. Harrington, Physico-chemical changes in bauxite residue following application of spent mushroom compost and gypsum, Land Degrad. Dev. 20 (2009) 572-581, http://dx.doi.org/10.1002/ldr.926.

[42] Q. Wang, J. Li, Y. Zhao, Z. Luan, Study on the dealkalization of red mud by suspension and carbonation, Chin J Environ Eng 3 (2009) 2275-2280. (in Chinese)

[43] Z. Wang, M. Han, Y. Zhang, F. Zhou, Study on the Dealkalization Technics of Bayer process Red Mud with $\mathrm{CO}_{2}$ by Carbonation, B Chin Ceram Soc 32 (2013) 1851-1855, http://dx.doi.org/ 10.16552/j.cnki.issn1001-1625.2013.09.043. (in Chinese)

[44] L.C.A. Venancio, J.E. Souza, A. Silva, E.N.A. Macedo, O.I. Dias, I.F. Santos, Measuring the $\mathrm{CO}_{2}$ captured on bauxite residue carbonation, Energy Technology 2013: Carbon Dioxide Management 
and Other Technologiesed., John Wiley \& Sons, Inc., 2013.

[45] T.S.S. Freire, M.W. Clark, M.J. Comarmond, T.E. Payne, A.J. Reichelt-Brushett, G.J. Thorogood, Electroacoustic isoelectric point determinations of bauxite refinery residues: Different neutralization techniques and minor mineral effects, Langmuir 28 (2012) 11802-11811, http://dx.doi.org/ 10.1021/la301790v.

[46] R.C. Sahu, R.K. Patel, B.C. Ray, Neutralization of red mud using $\mathrm{CO}_{2}$ sequestration cycle., J. Hazard. Mater. 179 (2010) 28-34, http://dx.doi.org/10.1016/j.jhazmat.2010.02.052.

[47] R.R. Lu, Y.H. Zhang, F.S. Zhou, X.K. Wang, Research of leaching alumina and iron oxide from Bayer red mud, Applied Mechanics \& Materials 151 (2012) 355-359, http://dx.doi.org/10.4028/ www.scientific.net/AMM.151.355.

[48] C.R. Borra, Y. Pontikes, K. Binnemans, T. Van Gerven, Leaching of rare earths from bauxite residue (red mud), Miner. Eng. 76 (2015) 20-27, http://dx.doi.org/10.1016/j.mineng.2015.01.005.

[49] P. Davris, E. Balomenos, D. Panias, I. Paspaliaris, Selective leaching of rare earth elements from bauxite residue (red mud), using a functionalized hydrophobic ionic liquid, Hydrometallurgy 164 (2016) 125-135, http://dx.doi.org/10.1016/j.hydromet.2016.06.012.

[50] K. Snars, R.J. Gilkes, Evaluation of bauxite residues (red muds) of different origins for environmental applications, Appl. Clay Sci. 46 (2009) 13-20, http://dx.doi.org/10.1016/j.clay. 2009.06.014.

[51] C.Z. Liao, L.M. Zeng, K.M. Shih, Quantitative X-ray Diffraction (QXRD) analysis for revealing thermal transformations of red mud, Chemosphere 131 (2015) 171-177, http://dx.doi.org/10.1016/ j.chemosphere.2015.03.034.

[52] R. Zhang, S. Zheng, S. Ma, Y. Zhang, Recovery of alumina and alkali in Bayer red mud by the formation of andradite-grossular hydrogarnet in hydrothermal process, J. Hazard. Mater. 189 (2011) 827-835, http://dx.doi.org/10.1016/j.jhazmat.2011.03.004.

[53] M.M. Radwan, H.K.A. El-Hamid, A.F. Mohamed, Influence of saline solution on hydration behavior of $\beta$-dicalcium silicate in comparison with biphasic calcium phosphate/hydroxyapatite bioceramics, Mat Sci Eng C 57 (2015) 355-362, http://dx.doi.org/10.1016/j.msec.2015.07.011.

[54] X.B. Zhu, W. Li, X.M. Guan, Kinetics of titanium leaching with citric acid in sulfuric acid from red mud, T. Nonferr. Metal. Soc. 25 (2015) 3139-3145, http://dx.doi.org/10.1016/S1003-6326(15) 63944-9.

[55] B.E.H. Jones, R.J. Haynes, I.R. Phillips, Influence of amendments on acidification and leaching of $\mathrm{Na}$ from bauxite processing sand, Ecol. Eng. 84 (2015) 435-442, http://dx.doi.org/10.1016/ j.ecoleng.2015.09.054.

[56] M.T. Tang, T.Z. Yang, Fundamental and technology of complex metallurgy, Central South University Press, Changsha, 2011. (in Chinese)

[57] M. Grafe, G. Power, C. Klauber, Bauxite residue issues: III. Alkalinity and associated chemistry, Hydrometallurgy 108 (2011) 60-79, http://dx.doi.org/10.1016/j.hydromet.2011.02.004.

[58] M.M. Reddy, L.N. Plummer, E. Busenberg, Crystal growth of calcite from calcium bicarbonate solutions at constant $\mathrm{P} \mathrm{CO}_{2}$ and $25^{\circ} \mathrm{C}$ : a test of a calcite dissolution model, Geochim. Cosmochim. Ac. 45 (1981) 1281-1289, http://dx.doi.org/10.1016/0016-7037(81)90222-2.

[59] Y. Liu, C. Lin, Y. Wu, Characterization of red mud derived from a combined Bayer Process and bauxite calcination method, J. Hazard. Mater. 146 (2007) 255-261, http://dx.doi.org/10.1016/ j.jhazmat.2006.12.015.

[60] M. Grafe, G. Power, C. Klauber, Review of bauxite residue alkalinity and associated chemistry, 
CSIRO Document DMR-3610, CSIRO: Clayton South, Victoria Australia, 2009.

[61] F. Zhu, Y.B. Li, S.G. Xue, W. Hartley, H. Wu, Effects of iron-aluminium oxides and organic carbon on aggregate stability of bauxite residues, Environ. Sci. Pollut. R. 23 (2016) 9073-9081, http://dx.doi.org/10.1007/s11356-016-6172-9.

[62] R. Courtney, T. Harrington, K.A. Byrne, Indicators of soil formation in restored bauxite residues, Ecol. Eng. 58 (2013) 63-68, http://dx.doi.org/10.1016/j.ecoleng.2013.06.022.

[63] F. Zhu, J.X. Liao, S.G. Xue, W. Hartley, Q. Zou, H. Wu, Evaluation of aggregate microstructures following natural regeneration in bauxite residue as characterized by synchrotron-based X-ray micro-computed tomography, Sci. Total Environ. 573 (2016) 155-163, http://dx.doi.org/10.1016/ j.scitotenv.2016.08.108.

[64] D.R. Neuville, L. Cormier, A.M. Flank, R.J. Prado, P. Lagarde, Na K-edge XANES spectra of minerals and glasses, Eur. J. Mineral. 16 (2004) 809-816, http://dx.doi.org/10.1127/0935-1221/ 2004/0016-0809. 


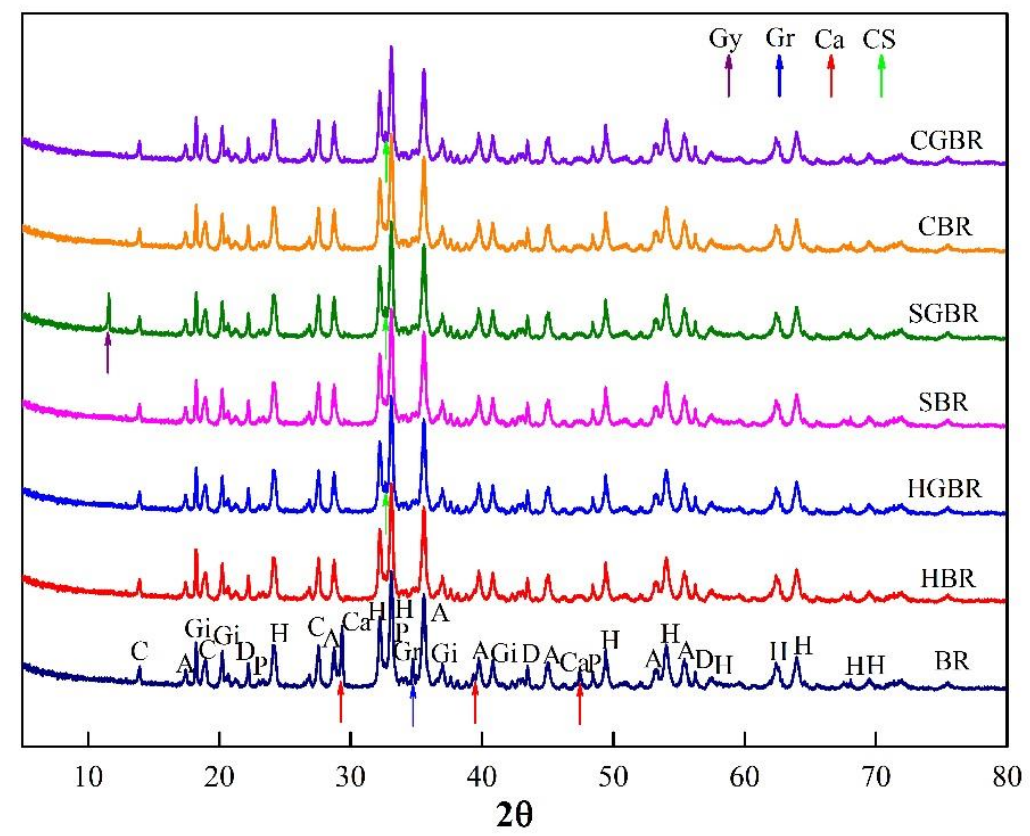

A-Andradite $\mathrm{C}$-Cancrinite $\mathrm{Ca}$-Calcite $\mathrm{CS}$-Calcium silicate $\mathrm{D}$-Diaspore H-Hematite Gi-Gibbsite Gy-Gypsum Gr-Grossular P-Preovskite

Fig. 1 XRD patterns collected from BR and TBR transformed by several methods. Where present, the strong peak of calcium silicate at $32.6^{\circ} 2 \theta$ was vaguely observed, being affected by the large peaks of andradite and hematite. 


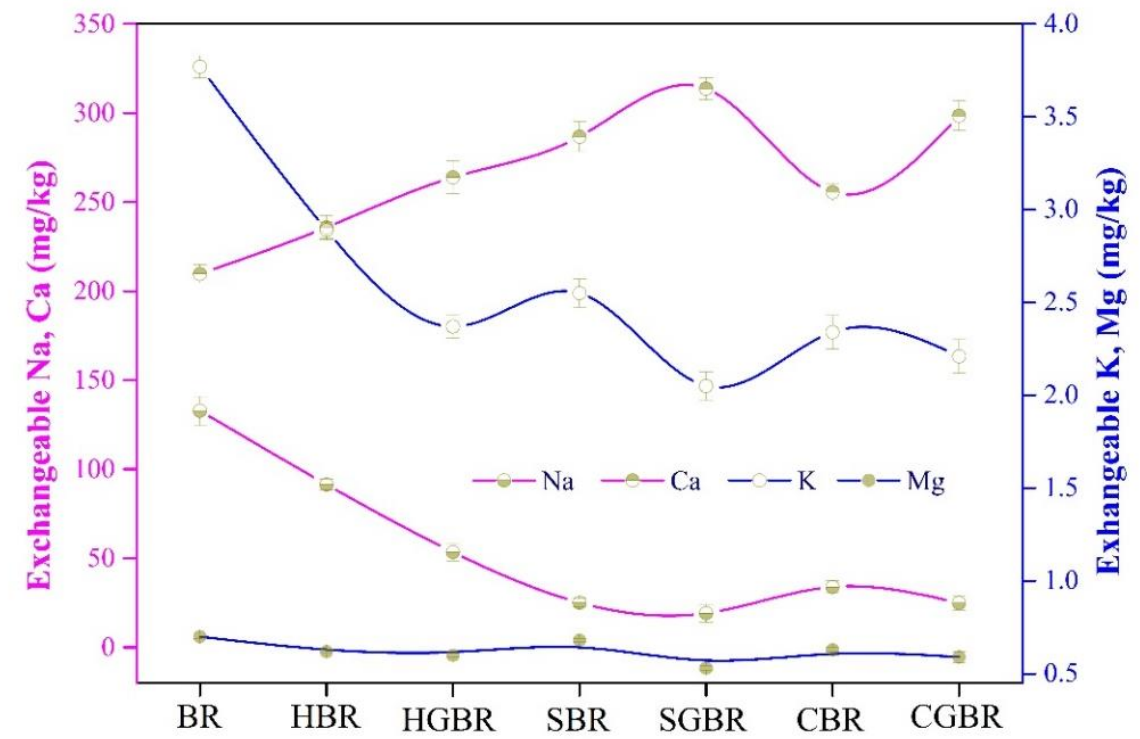

Fig. 2 Changes in exchangeable cations ( $\mathrm{Na}, \mathrm{K}, \mathrm{Ca}$, and $\mathrm{Mg}$ ) extracted by ammonium acetate from residual solids. Where present, no exchangeable $\mathrm{Al}$ and Fe were anticipated to exist in residues in alkaline conditions. 

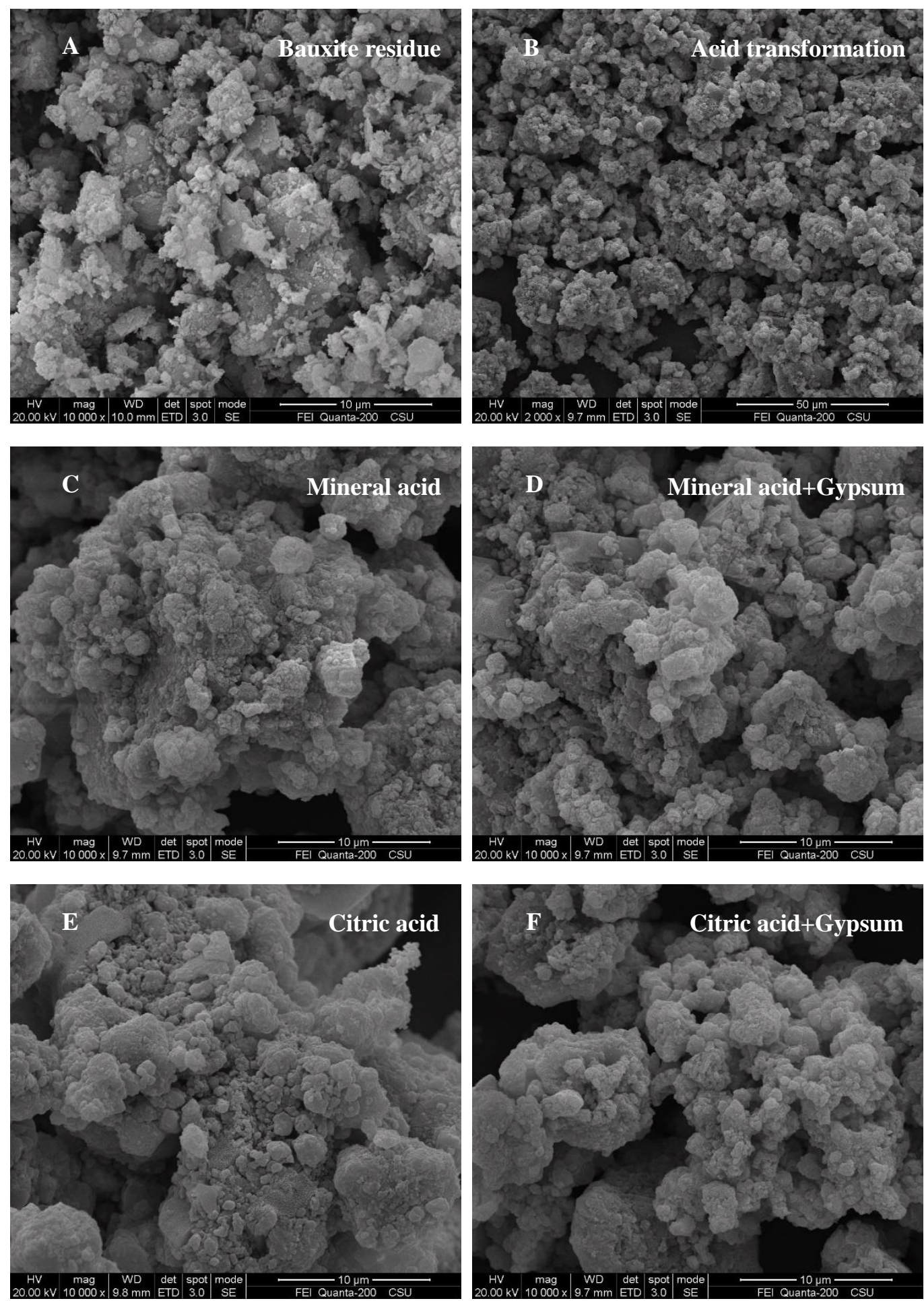

Fig. 3 High-resolution bright field SEM image of the BR (A), bauxite residue transformed by mineral acids (B, C and D), bauxite residue transformed by organic citric acid and gypsum combination (E and F). Figure B of TBR was treated by sulfuric acid and presented in a relatively low resolution (5000) to show aggregate distribution of residue particles. SEM images of hydrochloric acid and its gypsum combination were similar to sulfuric acid (Figures C and D), therefore mineral acids were used to simplify and represent the two acid types. 


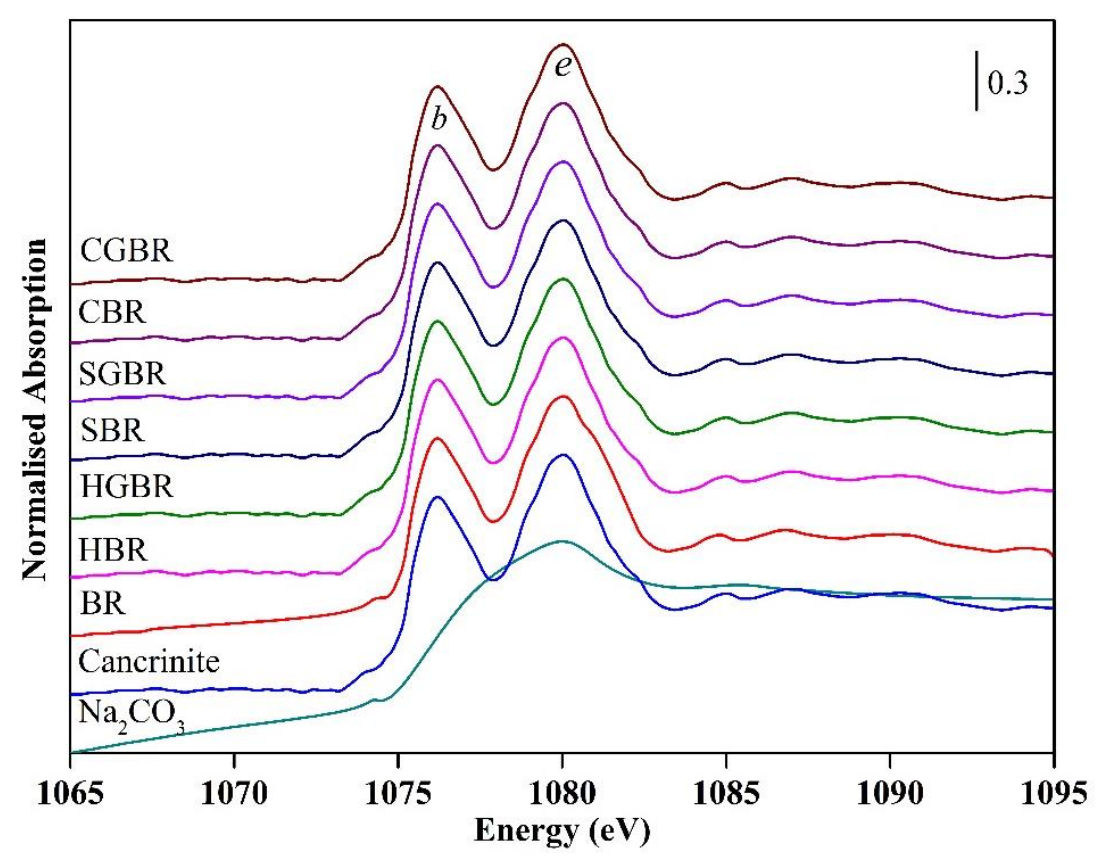

Fig. 4 Normalized Na K-edge XANES spectra collected from bauxite residue, transformed residues by different methods, and reference samples $\left(\mathrm{Na}_{2} \mathrm{CO}_{3}\right.$ and cancrinite). 

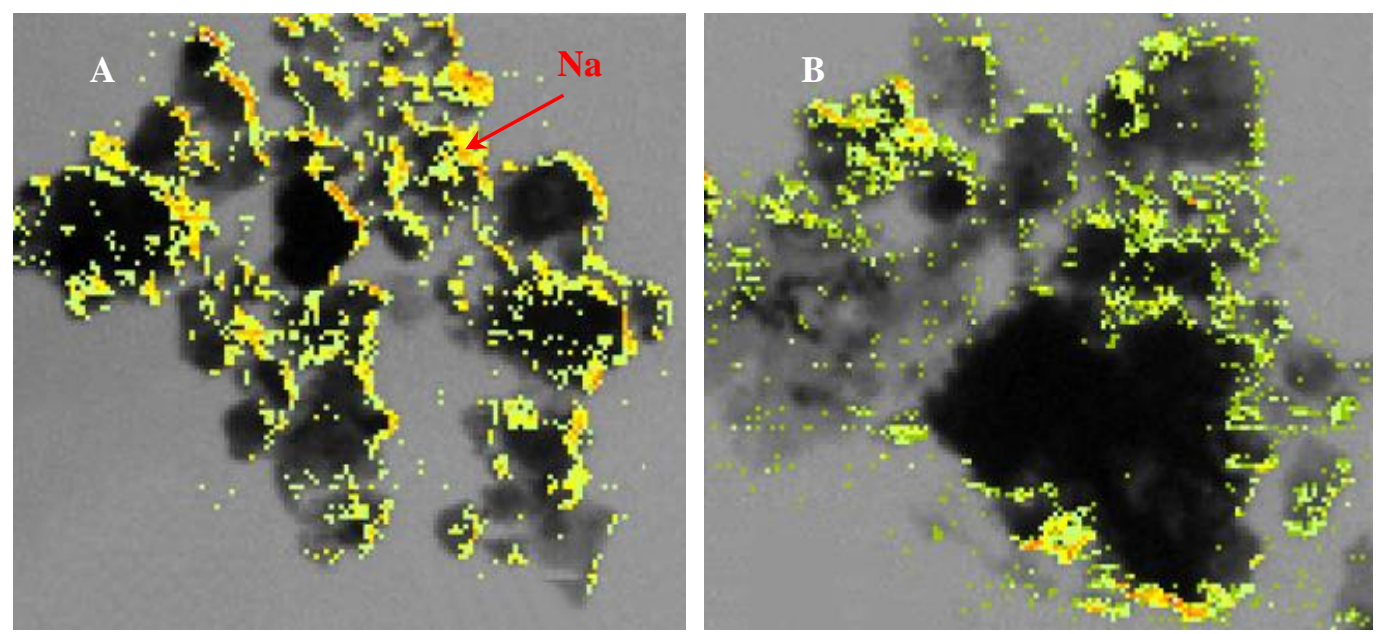

Fig. 5 Na STXM imaging by two-dimensional scan mode for BR (A) and TBR (B). TBR STXM imaging was represented by that of CBR. Photograph of bauxite residue transformed by mineral acids that were relatively similar to that of organic citric acid (CBR). Sodium STXM imaging of mineral acid transformations were expected to omit here. 
Table 1

Mineral composition of bauxite residue and transformed bauxite residue using different methods.

\begin{tabular}{|c|c|c|c|c|c|c|c|c|c|}
\hline \multicolumn{2}{|r|}{ Mineral phase } & & \multicolumn{7}{|c|}{ Transformation method } \\
\hline Name & Formula & units & $\mathrm{BR}$ & HBR & HGBR & SBR & SGBR & CBR & CGBR \\
\hline Andradite & $\mathrm{Ca}_{3}\left(\mathrm{Fe}_{0.87} \mathrm{Al}_{0.13}\right)_{2}\left(\mathrm{SiO}_{4}\right)_{1.65}(\mathrm{OH})_{5.4}$ & $\%$ & 28.4 & 30.4 & 29 & 31.6 & 28.9 & 33.5 & 32.8 \\
\hline Calcite & $\mathrm{CaCO}_{3}$ & $\%$ & 2.1 & - & - & - & - & - & - \\
\hline Cancrinite & $\mathrm{Na}_{8} \mathrm{Al}_{6} \mathrm{Si}_{6} \mathrm{O}_{24}\left(\mathrm{CO}_{3}\right)\left(\mathrm{H}_{2} \mathrm{O}\right)_{2}$ & $\%$ & 13.8 & 12 & 12.2 & 11.1 & 11 & 10.1 & 9.2 \\
\hline Diaspore & $\alpha-\mathrm{AlO}(\mathrm{OH})$ & $\%$ & 5.9 & 6.4 & 6.2 & 6.2 & 6 & 6 & 6.2 \\
\hline Gibbsite & $\mathrm{Al}(\mathrm{OH})_{3}$ & $\%$ & 2.4 & 8.1 & 8.3 & 7.6 & 7.3 & 6.8 & 6.4 \\
\hline Grossular & $\mathrm{Ca}_{3} \mathrm{Al}_{2} \mathrm{Si}_{3} \mathrm{O}_{12}$ & $\%$ & 5.2 & - & - & - & - & - & - \\
\hline Gypsum & $\mathrm{CaSO}_{4} \cdot 2 \mathrm{H}_{2} \mathrm{O}$ & $\%$ & - & - & - & $-a$ & 2 & - & - \\
\hline Hematite & $\mathrm{Fe}_{2} \mathrm{O}_{3}$ & $\%$ & 35.6 & 36.3 & 35.6 & 36.3 & 35.8 & 36.6 & 36.3 \\
\hline Perovskite & $\mathrm{Ca}(\mathrm{TiO} 3)$ & $\%$ & 6.6 & 6.8 & 6.7 & 7.2 & 6.8 & 7 & 6.8 \\
\hline Calcium silicate & $\mathrm{Ca}_{2} \mathrm{SiO}_{4}$ & $\%$ & - & $-b$ & 2 & $-b$ & 2.2 & $-b$ & 2.3 \\
\hline
\end{tabular}

${ }^{a}$ Gypsum generated by sulfuric acid transformation may exist in HBR, but the mineral content lowers the detection limit of X-ray powder diffraction. ${ }^{b}$ Produced calcium silicate phase in HBR, SBR and CBR are likely to be presented. 


\section{Table 2}

Alkalinity, pH, electrical conductivity and soluble cations for the supernatants of BR and TBR by different methods.

\begin{tabular}{|c|c|c|c|c|c|c|c|c|}
\hline Parameter & Units & $\mathrm{BR}$ & HBR & HGBR & SBR & SGBR & CBR & CGBR \\
\hline $\mathrm{pH}$ & units & $10.26 \pm 0.08$ & $7.87 \pm 0.11$ & $7.82 \pm 0.11$ & $8.22 \pm 0.09$ & $8.07 \pm 0.08$ & $8.49 \pm 0.20$ & $8.23 \pm 0.19$ \\
\hline $\mathrm{EC}$ & $\mathrm{mS} / \mathrm{cm}$ & $1.80 \pm 0.23$ & $4.08 \pm 0.17$ & $4.79 \pm 0.15$ & $4.36 \pm 0.21$ & $5.10 \pm 0.19$ & $3.95 \pm 0.13$ & $6.74 \pm 0.12$ \\
\hline Tot $\mathrm{Alk}^{a}$ & $\mathrm{~g} / \mathrm{L}$ & $28.35 \pm 2.17$ & $0.36 \pm 0.02$ & $0.17 \pm 0.01$ & $0.43 \pm 0.05$ & $0.22 \pm 0.01$ & $0.65 \pm 0.03$ & $0.33 \pm 0.01$ \\
\hline $\mathrm{S}^{b} \mathrm{Na}$ & $\mathrm{mg} / \mathrm{L}$ & $495.06 \pm 6.32$ & $1043.62 \pm 75.66$ & $983.39 \pm 66.14$ & $1327.98 \pm 120.32$ & $1353.83 \pm 112.46$ & $1627.24 \pm 96.34$ & $1990.69 \pm 100.26$ \\
\hline $\mathrm{S}^{b} \mathrm{~K}$ & $\mathrm{mg} / \mathrm{L}$ & $45.05 \pm 1.34$ & $63.00 \pm 2.68$ & $69.61 \pm 2.33$ & $61.33 \pm 2.02$ & $64.04 \pm 2.38$ & $59.68 \pm 1.98$ & $63.14 \pm 2.76$ \\
\hline $\mathrm{S}^{b} \mathrm{Ca}$ & $\mathrm{mg} / \mathrm{L}$ & $2.20 \pm 0.16$ & $829.21 \pm 3.22$ & $848 \pm 2.98^{c}$ & $899.32 \pm 40.12$ & $899.77 \pm 46.68^{c}$ & $745.12 \pm 12.32$ & $731.51 \pm 15.66^{c}$ \\
\hline $\mathrm{S}^{b} \mathrm{Mg}$ & $\mathrm{mg} / \mathrm{L}$ & $0.11 \pm 0.00$ & $0.50 \pm 0.01$ & $4.30 \pm 0.20$ & $7.40 \pm 0.90$ & $8.97 \pm 0.90$ & $3.88 \pm 0.10$ & $7.17 \pm 0.66$ \\
\hline $\mathrm{S}^{b} \mathrm{Al}$ & $\mathrm{mg} / \mathrm{L}$ & $8.34 \pm 0.48$ & $<0.001$ & $<0.001$ & $<0.001$ & $<0.001$ & $298.02 \pm 16.63$ & $300.00 \pm 7.02$ \\
\hline $\mathrm{S}^{b} \mathrm{Fe}$ & $\mathrm{mg} / \mathrm{L}$ & $<0.001$ & $<0.001$ & $<0.001$ & $<0.001$ & $<0.001$ & $<0.001$ & $<0.001$ \\
\hline
\end{tabular}

aTotal alkalinity is appropriate equivalent as aluminate, free hydroxide and carbonate, and all is expressed in mg/L

$\mathrm{Na}_{2} \mathrm{CO}_{3} .{ }^{b}$ Soluble cations, solube $\mathrm{La}, \mathrm{Li}, \mathrm{Ba}, \mathrm{Sc}, \mathrm{Se}, \mathrm{Sr}, \mathrm{Cr}, \mathrm{Cu}, \mathrm{Mo}, \mathrm{Zn}$ and $\mathrm{Zr}$ were detected in the supernatants, which were not showed and discussed herein. ' Soluble Ca didn't contain the original content of the additive gypsum that has been subtracted in terms of the assume of absolutely dissolvable ability of gypsum in the transformation process. 